\title{
Ecopreneurship Implementation for Environment and Economic Sustainability
}

\author{
Sony Sasongko \\ School of Postgraduate Studies \\ Universitas Pendidikan Indonesia \\ Bandung, Indonesia \\ sony.sasongko@gmail.com
}

\author{
Grisna Anggadwita \\ School of Economic and Business \\ Telkom University \\ Bandung, Indonesia
}

\begin{abstract}
Ecopreneurship is an entrepreneurial activity based environment to meet their business objectives that impact on economic sustainability. Small Business is one of the sectors that have the potential to develop ecopreneurship business concepts. This paper focuses on how to exploit the potential of innovative entrepreneurs based environment so as to encourage more startups to tackle environmental problems. This paper also discusses the role of entrepreneurship education in promoting ecopreneurs behavior and presented an outline of possibilities that can be integrated into entrepreneurship education at college level. This study aims to explore the concept of ecopreneurship in small business in Bandung, Indonesia. Qualitative method is taken as the research method by conducting in-depth interviews with ecopreneurs in Small Business in Bandung, Indonesia. Based on the study concluded that collaboration between, environment, social, and economy are key factors in ecopreneurship implementation. By organizing and flow synthesis of previous research studies, this study provides a comprehensive framework for future studies to ecopreneurship dimension, so it can be used to evaluate the state of environmental innovations Ecopreneurship in Indonesia.
\end{abstract}

Keywords- Economic Sustainability; Ecopreneurship; Entrepreneurship Education; Environment Entrepreneurs; Innovative Entrepreneurs.

\section{INTRODUCTION}

Innovations can change economy and society fundamentally. In creating an innovation, a company should be able to overcome limitations. Sustainable development needs continuous innovations and the entrepreneur who can achieve the environment purposes with superior innovations will be successful in the market. Entrepreneurship is viewed as a process of finding market opportunities and organization resources which are needed to use the opportunity to gain long term results. The player and the company who have creative and innovative abilities for environment advancement in their core business are called 'ecopreneurs'.

Ecopreneurship is an entrepreneurship concept which is not profit oriented only but also concern to other aspects, especially the environment aspect. Ecopreneurship is an entrepreneurship behavior which focusing on the environment sustainability in the future. Based on data reference [1], the amount of new venture, small and medium enterprises (SMEs) has achieved 300 thousand. The SMEs contribution to Bruto Regional Domestic Product (BRDP) in Bandung in 2011 is
$58,62 \%$ [2]. According to SMEs business field in Bandung are mostly in commerce and industry sectors, hotels and restaurants. This is an opportunity for ecopreneurs to produce products, services, techniques and organizations model which substantially reduce the environmental impact and increase the quality of life. One of ecopreneur focuses is to use the waste from productions into something useful and economical value.

According to [3], ecopreneurship is a combination of two words, ecology (eco) and entrepreneurship. Ecopreneurship is entrepreneurial activities through the environment lenses. Ecopreneurship is marked with several fundamental aspects from entrepreneurial activities which oriented to management system or technical procedures and more focused on the initiatives and personal or team skills to achieve market success with environmental innovations. Reference [3] stated that a positive environment impact for companies should give real and substantial contributions for the development of the environment. A big contribution would make a company gives a significant market impact or by influencing the competitors and other businesses to adopt an excel environment solutions. A business which is capable to offer solutions for social problems and especially focusing on ecology issues is called 'Green Entrepreneurship' or 'Ecopreneurship' [4].

The purpose of this research is to acknowledge the ecopreneurship implementation concept in SMEs in Bandung, Indonesia. Ecopreneurship implementation is used as a way to foster the society's concern to the environment, to improve the environment condition, and to increase economy by building an independent society to gain mutual benefits. This research proposes a conceptual model and suggests practical milestones that can be taken to encourage ecopreneurship in new policies framework and promotes Ecopreneurship.

\section{WHAT IS ECOPRENEURSHIP}

An entrepreneur is a catalyst who unites money, people, ideas, and resources. All entrepreneurs are bridging activities between the suppliers and customers to create and to make market changes, ecopreneurs are different with conventional entrepreneurs where they also build the bridge between environment advancement and market success. Ecopreneurs show personal mastery [5] and consider their professional life as creative actions. Ecopreneurship can be describe as a form of market orientation and innovative value creation driven through environment and product innovations. 
Ecopreneurship is distinguished from the form of company environment development and the company commitment for environment improvements and strong will for business growth. The focus is on environmental sustainability to gain the momentum in business environment. This trend has created various opportunities for entrepreneurs: creating green technology, using technology to promote environmental sustainability (energy management for example) to make existing business environmental friendly, thus profits and benefits can be obtained. An ecopreneur is not just a person determined by possibilities of making profits, but also determined by environmental issues. An ecopreneur would like to make the world a better place by increasing, or at least protecting the environment. Ecopreneurs identify environmental innovations and their market opportunities to successfully change these innovations into new products or services [6]; [7].

The academics focus and researchers to ecopreneurship has begun from 1990s, several writers in details discuss about environment oriented entrepreneurship [6 - 18]. Reference [3] in the research discuss the ecopreneurship measurement framework. He mentioned that there are five dimensions of ecopreneurship that can be measured including environment purposes and policies, various ecology products and services, market share, sales growth, and competitor reactions. The main benefit of this framework is providing self-assessment and the opportunity for improvements. Green entrepreneurship is a relatively new area but offers several opportunities to business sustainability through innovations. However, the law regulations and industries supporting institutions should play important roles in making this activity successful. SMEs, venture investors, and local society can play important roles to ensure the ecopreneurship success. Reference [19] mentioned that ecopreneurship has emerged from finding solutions for environmental problems throughout the world. Therefore, ecopreneurship is related to environmental friendly ways to do business. According to [19], there are three important elements to achieve success in ecopreneurship, which are: ecoinnovation, eco-commitment, and eco-opportunity. Reference [20] mentions that ecopreneurship is about how to gain competitive advantage through the entrepreneurial spirit and approaches.

Interactions between personal motivations and external factors as drivers of ecopreneurial activities have been used to build ecopreneurs typology. Reference [21] build the typology based on Giddens ideas about social; structures and actions, whereas ecopreneurial activities are emerging as the actual embodiment of entrepreneurs sustainability. Ecopreneurship typology is based on two axes: Structural influence and personal orientation/motivation. The four types of ecopreneurs are: Innovative Opportunists who identify green niche for economy exploitations and is mainly influenced by structural factors, such as government regulations; Visionary Champions who manage the business sustainability to change the world and the establishment business based on the environmental sustainability; Ethical Mavericks who are influenced by soft structural drivers (such as past experiences, network or friends) and sustainability oriented; and, $A d$ hoc enviropreneurs who are encouraged by financial factors, but influenced by soft structural driver.

Ecopreneurship is viewed as existence form of business behavior committed to sustainability. This research gives several practical suggestions for business players who would like to try the ecopreneurial strategy which is the sustainability business development with the focus on the balance between the environment, social, and economy.

\section{CONCEPTUAL MODEL OF ECOPRENEURSHIP}

According to [22], in running the business we should pay attentions to $3 \mathrm{P}$ which are profit, people, and planet. For development sustainability, there should a collaboration between economy, social, and environment. Ecopreneurship should be able to collaborate all three elements of development sustainability. Ecopreneurship is influenced by structural and personal orientation/motivations. This research proposes the conceptual model which is shown in figure 1 below.

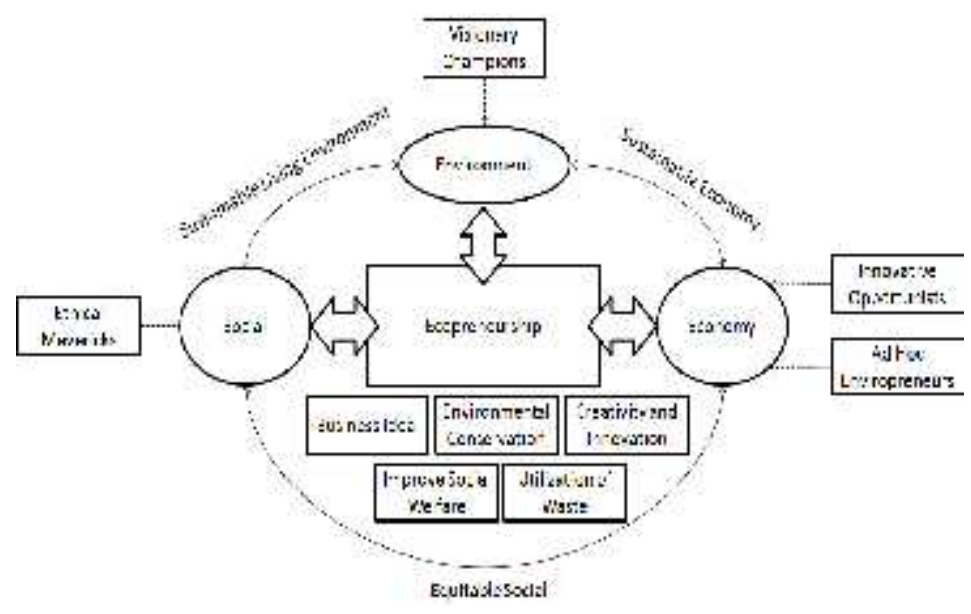

Fig. 1. Conceptual Model

Figure 1 shows that ecopreneurship activities emerge influenced by economy, social, and environment factors. The balance of three factors will give business ideas, environmental conservation, creativity and innovation, social welfare improvement, and utilization of waste. Ecopreneurship is a new concept for economy, social and environmental sustainability.

\section{Research Methodology}

Qualitative method conducted with the approach of observation, interviews and document collection which is then the analysis results interpreted in the form of words and pictures [23]. Thus, this study used a qualitative descriptive approach to exploring and understanding the findings of research conducted [24]. The object of this study is the implementation ecopreneurship with research subjects are business people in West Java that has implemented ecopreneurship. Data collected through interviews and observations. Primary data were obtained through semi- 
structured interviews with a purposive sample by three entrepreneurs who are already implementing the concept of ecopreneurship. Meanwhile, secondary data obtained through the company's data, internet, and other references. Data analysis is divided into stages that include data examination from multiple sources, data reduction, categorization, data validity and interpretation of data. This method is expected to reduce bias, including data triangulation process. A conceptual model proposed in this study is based on interviews and review of previous literature synthesis.

\section{ECOPRENEURHSIP IMPLEMENTATION}

\section{A. Profile of Respondents}

This research identifies the ecopreneurship implementation concept based on the conceptual model of this research. Three sources have agreed to give information related to the ecopreneurship implementation concept, which are "Giva Art Craft", "Sartika Kreasindo", and "Hi-Cup". In-depth interviews and semi-strukture have been done with the three sources. These three sources have been managing their businesses around 2-3 years with employees of 5-10 people. There was even a source that created the barter system which is the exchange of plastic waste with money; this helps the local society increasing the economy. The businesses of these three sources is in the recycled field, whereas the use the environment waste and one of them is plastics, which has become creative products such as accessories and water bottles. The three sources have commitments to reduce plastics waste, considering plastics rubbish phenomena are rubbish which need hundreds of years to decompose. Currently, plastics productions are huge and the potential of plastics waste produced is very big and impacted to living environmental sustainability.

The price range offered for every product is various. This will depend on the materials and the difficulty level of making. For every promotion they have used the search engine optimization with managing website, WordPress, blogs, YouTube, social media such as Facebook, Instagram, also there are telephones, SMS, and instant messaging media such as WhatsApp and line which will be easy to contact them when ordering products. Marketing activities are conducted such as exhibitions, events campaign, and inauguration ceremonies.

Their customers are from all over Indonesia, as they are using delivery service such as JNE, TiKi, the post office, and etc. Not only domestic's customers but there are customers from the Netherland, Germany, Australia and Malaysia. The bigger these businesses developments, the bigger business opportunities for society welfare in the recycled products businesses are.

\section{B. Case Study}

Based on the interview with three sources, they have similarities which are being the Visionary Champions [21]. This means they will always manage the business sustainability to change the world. Their established business is based on the desire to achieve environmental with strong self-motivation. Not only they want to prosper themselves, but they also want to prosper their own society. This study supported the statement from [16] that the business exist to support the alternative lifestyle, it means that their business should spread the positive influence to foster love for the environment and actively participate in the community to preserve the environment.

Starting from the simple steps which are separating the organic and inorganic trash, and choosing types of trash that can still be used in producing the recycled products, together they want to establish waste banks in their own region. Rubbish such as glass, used packaging plastics, leaves, newspapers, magazines, tins, cigarettes packs, used papers, plastics water bottle, sands, and wood pulp. All these rubbish, the type that can be produced into art crafts, are separated and gathered.

The local community empowerment has become optimal. Starting from PKK women, teenagers who are involved in Community Development (in Indonesia called with "Karang Taruna"), local community who would like to participate in this activity, also the school age children who are taught creating from the used matters in their homes. From the beginning until today, the three sources have been actively making tutorial classes about how to process waste into useful matters, conducting special trainings to learn ways of making unique art crafts with high economic value.

These activities have been supported by many sides such as Bandung mayor, Indonesia citizens, and media televisions, well known event organizers (PT Djarum Super and many more). Various awards are given for the embodiment of awareness by these three sources in conducting art craft businesses using waste and recycled products. This means that their smallest actions which inspire the community will help the community awareness of waste problems, especially in Bandung.

So what distinguish recycled products that they excel? The answer is their level of creativity. Creativity from the waste processing into useful products is the process or the ability that reflects the smoothness, flexibility, originality in thinking, also the ability to elaborate (developing, enrich, and detailing) existed ideas. Basically creativity [25] involves the generation of new ideas or the recombination of known elements into something new, providing valuable solutions to a problem.

The product of creativity can become something new; it can also be combination of previous data or elements to produce something different. This depends on how they create the art crafts to be unique with added value. Brainstorming between sources and the community is the cornerstone where everyone can express their ideas to be achieved as realization. The result of brainstorming which are agreed will be applied in the production of recycled products. This means there is an appreciation which makes the community feel involved in keeping the environmental sustainability.

If the activities are continuously managed, then the environment will become more sustain. This is caused by the community which has started to do simple things that will give big impacts to the reducing of existed waste. Eventually the 
environment will be clean and the level of pollution will be reduced. This has long term positive influence if the community continues activities with full of responsibility and full of awareness to keep the environmental sustainability.

Not only keeping the natural surroundings, there is another benefit which is developing community's economy. As we all know that ecopreneur is an entrepreneurship concept which is not only profit oriented but also aware to other aspects, especially the environment aspect. Ecopreneurship is the entrepreneurship behavior which concern or prioritize the future environment continuous sustainability. The rubbish issues related to this education and how the study about ecopreneur will affect to sustainability of the existed environment. The more creative the products they make; the more customers will be loyal to buy those products. Companies contribute most to the enhancement of economic and social welfare if their core business is able to provide solutions to the environment and create a superior product innovations that are environmentally friendly as well influence the market demand in large quantities [16].

\section{CONCLUSION}

Ecopreneurship has fostered the community's awareness to the environment because it has succeeded to disenchant community that environment needs to be preserved by reducing rubbish and separating organic and inorganic rubbish, thus the recycled product process is easier and flexible. Simulations and trainings which are given to community about ways to improve their environment not to be polluted are simple, so anyone is capable to do so. This education eventually has an important role to keep the environment preservation. Ecopreneurship has also increased the economy to build independent community in gaining mutual benefits. Individual creativity needs to be raised and supported by good cooperation between one another to increase the profit. If this effort is continuously developed, it will result in mutual community economy growth, not just the individual benefits that will be developed. Thus, collaboration between, environment, social, and economy are key factors in ecopreneurship implementation. This research conceptual model can be used by entrepreneurs, academics, government, and others who are benefited from the ecopreneurship concept implementation. Further research can be conducted with empirical test of proposed model, and to test the appropriateness of this model.

\section{REFERENCES}

[1] Department of Cooperative, SMEs, Industry and Trade of Bandung, Jumlah Usaha Mikro, Kecil, dan Menengah, [online] http://bandung.go.id, accessed 20 September 2015.

[2] Department of Cooperative, SMEs, Industry and Trade of Bandung, Produk Domestik Regional Bruto (PDRB), [online] http://bandung.go.id, accessed 20 September 2015.
[3] Schaltegger, S., A framework for ecopreneurship, Greener Management International, 2002(38), 45-58.

[4] Schaper, M., Introduction: the essence of ecopreneurship, Greener Management International, 2002(38), 26-30.

[5] Senge, P., Die Fünfte Disziplin: Kunst und Praxis der lernenden Organisation (The Fifth Discipline: Art and Practice of the Learning Organisation), Stuttgart: Klett-Cotta, 1996.

[6] Lober, D.J., Pollution Prevention and Corporate Entrepreneurship, Journal of Organisational Change Management 11.1, 1998, pp. 26-37.

[7] Pastakia, A., Grassroots Ecopreneurs: Change Agents for a Sustainable Society, Journal of Organisational Change Management 11.2: 1998, pp. 157-73.

[8] Anderson, T., and D. Leal, "Enviro-capitalism: Doing Good while Doing Well”, Lanham, MD: Rowman Littlefield, 1997.

[9] Bennett, S.J., "Ecopreneuring: The Complete Guide to Small Business Opportunities from the Environmental Revolution”, New York: John Wiley, 1991.

[10] Berle, G., "The Green Entrepreneur: Business Opportunities that can Save the Earth and Make you Money", Blue Ridge Summit, PA: Liberty Hall Press, 1991.

[11] Blue, J., "Ecopreneuring: Managing for Results", London: Scott Foresman, 1990.

[12] Isaak, R., "Green Logic: Ecopreneurship, Theory and Ethics", Sheffield, UK: Greenleaf Publishing; West Hartford, CT: Kumarian Press, 1998.

[13] Keogh, P.D., and M.J. Polonsky, "Environmental Commitment: A Basis for Environmental Entrepreneurship?", Journal of Organisational Change Management 11.1: 1998, pp. 38-49.

[14] Kyrö, P., "To Grow or Not to Grow? Entrepreneurship and Sustainable Development", International Journal of Sustainable Development and World Ecology 8.1: 2001, pp. 15-28.

[15] Larson, A.L., "Sustainable Innovation through an Entrepreneurship Lens", Business Strategy and the Environment 9: 2000, pp. 304-17.

[16] Schaltegger, S., and H. Peterson, "Ecopreneurship: Konzept und Typologie (Ecopreneurship: Concept and Typology)", Lüneburg, Germany: Centre for Sustainability Management; Lucerne, Switzerland: Rio Management Forum, 2001.

[17] Staber, U., "An Ecological Perspective on Entrepreneurship in Industrial Districts", Entrepreneurship and Regional Development 24.1: 1997, pp. $37-48$.

[18] Wiklund, J., "The Sustainability of the Entrepreneurial OrientationPerformance Relationship", Entrepreneurship: Theory and Practice 24.1: 1999, pp. 37-48.

[19] Kainrath, D., "Ecopreneurship in theory and practice: A proposed emerging framework for ecopreneurship", Faculty of Social Sciences, Umea School of Business, Umea University, Sweden, 2009. Retrieved from http://umu.diva-portal.org/smash/record.jsf?pid=diva2:280302

[20] Holger, P, "Ecopreneurship and competitive strategies", Managing the Business, 2006.

[21] Walley, L. and Taylor, D., "Opportunity Champions, Mavericks...?", Greenleaf Publishing, Summer 2002.

[22] Elkington, J., Cannibals with Forks : The Tripple Botton Line of 21st Centaury Business, Oxford. UK : Capstone, 1997.

[23] Dhewanto, W., Lantu, DC., Herliana, S., and Anggadwita, G., The Innovation Cluster of ICT Start-Up Companies in Developing Countries: Case of Bandung, Indonesia, International Journal of Learning and Intellectual Capital 2015, 12 (1), 32-46.

[24] Moleong, Lexy J, Metode Penelitian Kualitatif. Penerbit : PT. Remaja Rosdakaya Offset, Bandung, Indonesia, 2009.

[25] Sefertzi, Eleni., “Creativity”, Innoregio Project, 2000. 